\title{
Professionals and interfamily violence against children and adolescents: in between legal and conceptual precepts*
}

\author{
Os profissionais e a violência intrafamiliar contra crianças e \\ adolescentes: entre os preceitos legais e conceptuais \\ Los profesionales y la violencia intrafamiliar contra niños y \\ adolescentes: entre los preceptos legales y conceptuales
}

Gabriele Schek ${ }^{1}$, Mara Regina Santos da Silva ${ }^{1}$, Carl Lacharité ${ }^{2}$, Maria Emilia Nunes Bueno ${ }^{1}$

How to cite this article:

Schek G, Silva MRS, Lacharité C, Bueno MEN. Professionals and interfamily violence against children and adolescents: in between legal and conceptual precepts. Rev Esc Enfem USP. 2016;50(5):779-784. DOI: http://dx.doi.org/10.1590/S0080-623420160000600010

* Extracted from the thesis "Práticas Profissionais que silenciam a violência intrafamiliar contra crianças e adolescentes: um estudo em contextos institucionais", Universidade Federal do Rio Grande, 2016.

${ }^{1}$ Universidade Federal do Rio

Grande, Rio Grande, RS, Brazil.

${ }^{2}$ Université du Quebec à Trois-Rivières, Trois-Rivières, QC, Canada.

\begin{abstract}
Objective: To identify the conceptions of professionals regarding interfamily violence against children and adolescents. Method: A qualitative study conducted with 15 professionals who had taken children and adolescents under their care as a result of interfamily violence. Data were collected between November, 2013, and March, 2015, through semi-structured interviews. Data were organized and analyzed using the Textual Discourse Analysis technique. Results: The professional discourse highlighted that some legal aspects regarding the handling of interfamily violence against children and adolescents are neglected; an omission supported by the justification of professionals to preserve the family. We highlight the confrontation between the concept of family as a caregiver and the family that commits violence against children, in addition to the positioning of professionals, which does not include the family or the aggressor in the intervention process in facing situations of interfamily violence attended to by the services. Conclusion: Acting against interfamily violence requires professionals to do away with some pre-established concepts in ordee to put the actual needs of victims and families into evidence.
\end{abstract}

\section{DESCRIPTORS}

Child; Adolescent; Family; Domestic Violence; Professional Practice. 


\section{INTRODUCTION}

Interfamily violence against children and adolescents is defined as acts or omissions carried out by parents, relatives or guardians, which may cause pain or physical, psychological and/or sexual damage to the victim ${ }^{(1)}$. This type of violence can generate feelings such as anger and depression, self-destructive and suicidal behavior, and learning problems that are manifested in childhood. In adulthood, victims of interfamily violence may have relationship problems, with fragile and insecure emotional ties, difficulty in dealing with their own feelings, as well as repeating violence with their own children and other family members, supporting the idea that this phenomenon occurs in a cyclical manner ${ }^{(2-5)}$.

According to data from UNICEF, six of every 10 children between 2 and 14 years of age are victims of interfamily violence through physical punishment and psychological aggression. In Brazil, it is estimated that there are on average 129 cases of violence including physical, sexual, psychological and neglect reported to the Allegation Hotline daily, thus representing a public health problem ${ }^{(6-7)}$. It is estimated that this number may be even higher, as many of these crimes will not be reported.

Based on the Brazilian Federal Constitution of 1988 and the Statute of Children and Adolescents (ECA), one of the most widespread official documents when it comes to violence, it is the duty of the family, society and the State to ensure the rights of children and adolescents, including the right for life, food, education, dignity and respect, keeping them safe from all forms of negligence, discrimination and violence $^{(4,8)}$. Thus, from a legal point of view, the professionals who work in services that treat children and adolescents have specific responsibilities. Among these, notification of suspected and/or confirmed cases to the Guardian Council, as well as to form intervention strategies that address victims and families in order to minimize the effects or to interrupt the cycle of violence ${ }^{(4)}$.

Even when faced with such responsibilities, the World Health Organization (WHO) highlights, for example, that only $2 \%$ of violence cases occurring in the family are notified by professionals ${ }^{(6)}$. In addition, researchers point to the invisibility of violence within health institutions in view of the underreporting rates of cases $^{(9)}$.

Literature highlights the unpreparedness of professionals to act against interfamily violence, relating it to a lack of knowledge regarding the signs and symptoms that may be indicative of violence, a lack of institutional support for solving cases, and the very way in which this phenomenon is conceived by some professionals ${ }^{(10-12)}$. The social acceptance of some forms of violence stands out as a method of disciplining children and adolescents, in addition to the fear of some professionals that they may harm the victim if they adopt measures that could lead to the victim being withdrawn from their family environment. As a whole, these aspects delay the diagnostic procedures and intervention against the phenomenon.

In this perspective, the authors defend the idea that people's attitudes do not exist in the abstract, but are linked to their conceptions, values and feelings with which they mutually interact ${ }^{(13)}$. In order to give visibility to these issues and more importantly to relate them to professional practices facing interfamily violence against children and adolescents, this study was developed with the theoretical support of Institutional Ethnography (IE) which focuses on professional discourse, considering that it conveys different ideas about a phenomenon constituting regulatory elements and coordination of what can be said or done in the institutional context.

From these considerations, this study aims to identify the professionals' conceptions regarding interfamily violence against children and adolescents based on their discourse.

\section{METHOD}

This is a qualitative study carried out with 15 professionals, who had children and adolescents under their care due to presumed or confirmed interfamily violence. Of these, six are nurses, two are psychologists, two are doctors, two are community health agents, two are counselors and one is a social worker.

The professionals were recruited from services that treat children and adolescents who are victims of interfamily violence, including an Emergency Care Unit and Pediatrics Unit of a University Hospital, a Basic Health Unit, a Specialized Reference Center for Social Assistance and a Child Protection Agency, located in a medium-sized city in Southern Brazil. The first two aforementioned institutions represent the gateway for child and adolescent victims of interfamily violence in the health system, while the last two are social institutions specifically designed for assisting interfamily violence cases. The decision to include these services in the study was due to the fact that, as a whole, they portray the route usually taken by families in situations of violence in this municipality, and attend to a significant number of victims every month.

Data were collected between November, 2013, and March, 2015, through semi-structured interviews conducted individually at the professionals' workplace. These interviews were guided by a script that included an investigation of the professional's conceptions regarding interfamily violence against children and adolescents. To preserve anonymity, the professionals are identified by the letter $\mathrm{P}$, followed by a health or social denomination, which corresponds to the operation area for each of the professionals interviewed, followed by a number 1, 2, 3 ..., corresponding to the order in which the interviews were conducted. Example: $\left(\mathrm{P}_{\text {health } 1}\right)$; $\left(\mathrm{P}_{\text {social } 2}\right) ;\left(\mathrm{P}_{\text {social } 3}\right)$. This study was approved by the Research Ethics Committee of the institution to which it is linked, under registration number 066/13.

Data were organized and analyzed using the Textual Discourse Analysis technique ${ }^{(14)}$, guided by the following steps: breaking down the interviews, identifying the conceptions present in the professionals' dialogue regarding interfamily violence against children and adolescents, forming the analysis units, then building relationships between those units was prepared by grouping their elements into three categories which received the following designations: 
Professional Negligence supported by the justification of preserving the family; confrontation between the concept of family as a caregiver and family that commits violence against children; Professional positioning in face of interfamily violence against children and adolescents.

\section{RESULTS}

Among the study participants, 14 were female and one was male, with a mean age of 46 years. The institutional affiliation time varied between 12 and 240 months. Twelve professionals had additional training, with an emphasis on specializations in the areas of Public Health and Family health.

Of the six nurses who participated in this study, three work in a university hospital in the areas of pediatrics and Emergency Care, and three integrate Family health teams of a Basic Health Unit which is located on the periphery of the city. The two doctors and two community health agents are connected to the same Basic Unit. Both counselor respondents integrate different teams. Two psychologists and the social worker develop their professional activities in a Reference Center specializing in Social Assistance.

\section{Professional Negligence supported by the JUSTIFICATION OF PRESERVING THE FAMILY}

Although the professionals of this study recognize interfamily violence against children and adolescents as a problem that could affect the health and development of the victims, this phenomenon still does not constitute an objective of intervention, leading them to develop actions overlooking the fact of a family harboring a problem.

The discourse of most interviewed subjects highlights the fact that violence against children and adolescents is still being conceived as a private matter of the family, which can determine how they want to deal with the problem. In this perspective, some subjects believe that given situations of interfamily violence against children and adolescents, it is necessary to "act with caution" since a report or notification of the case can contribute to what they call "family disintegration/breakdown," culminating in marital separations and the victim being withdrawn from the family environment, which is not always regarded as the best approach to take.

(...) These situations are difficult, because depending on how you act, you can disrupt an entire family $\left(\mathrm{P}_{\text {healt } 6}\right)$.

(...) Sometimes it is complicated because I do not know to what extent it is beneficial to remove the child from the household and send them to a shelter $\left(\mathrm{P}_{\text {health }}\right)$.

Faced with suspicious situations and even confirmed domestic violence against children and adolescents, some professionals end up neglecting the information obtained during consultations with victims, thus failing to register them in the medical records, and not complying with the legal aspects involved in managing these situations; among them being to fill in the Notification Form/Individual investigation of domestic, sexual and/or other interpersonal violence. The neglect of these aspects is justified by some professionals by considering the will of the family itself, who try not to expose the problem, and to avoid "a family breakdown" that could be caused if the violence constituted an outside problem.

(...) Sometimes we don't have a way out, because the things that are said in the clinic cannot leave here, the family itself does not want it to $\left(\mathrm{P}_{\text {health } 6}\right)$.

\section{THE CONFRONTATION BETWEEN THE CONCEPT OF FAMILY AS A CAREGIVER AND FAMILY THAT COMMITS VIOLENCE AGAINST CHILDREN}

For participants of the study, caring for others is something inherent to the human being, and therefore everyone should know how to perform this role. Specifically in relation to the family, there is an important social role of taking care of its members, especially children and adolescents, since they are vulnerable beings and dependent on the care of their parents. Thus, for some professionals imagining that there are families unable to exercise this care is difficult to accept.

(...) Some situations are shocking, because when you think about family, you consider it as your safe haven. However, you end up seeing that coming from there is what threatens you, what causes you suffering $\left(\mathrm{P}_{\text {social } 2}\right)$.

In the professional discourse, it was possible to identify some of the conceptions that underlie the mother's social role in relation to caring for their children. Meaning that, from the perspective of the respondents, the mother represents the primary caregiver, so when she "fails" in this role, some professionals start to make judgments that label them as complicit with situations of violence.

(...) Sometimes the mothers know that the child is being abused or suffering violence and they allow this to happen. That's pretty hard to accept $\left(\mathrm{P}_{\text {social } 9}\right)$.

Influenced by such conceptions, professionals have different ways of acting when facing cases of violence in their daily lives. Some respondents seek withdrawal from the situations.

(...) That affects me a lot, I even keep a certain distance from the family. $\left(\mathrm{P}_{\text {health } 3}\right)$, while others end up adopting a more incisive approach, endowed with insults aimed at disapproving the behavior/attitude of the family.

(...) Once I told her (to a mother): you are a coward, go hit someone your own size. $\left(\mathrm{P}_{\text {health } 7}\right)$.

\section{Professional positioning in faCe Of INTERfamily VIOLENCE AGAINST CHILDREN AND ADOLESCENTS}

In situations of interfamily violence against children and adolescents, the professionals who participated in this study have chosen to adopt a position that ends up judging and sentencing the families and the agents of the aggression. Most times the abuser is associated to the man (father or stepfather), who is seen as a subject devoid of any feelings and values, and who therefore should receive some form of punishment. 
Although most interviewed subjects are healthcare professionals, only two considered the need to offer rehabilitation options to the aggressor, thus giving them the opportunity to reflect and especially to change their behavior. This perspective is reiterated from the understanding of $\left(\mathrm{P}_{\text {Health } 6}\right)$, who conceived the aggressor as a sick human being who was probably subjected to some form of violence during their childhood, which contributes to such actions being reproduced in the family context.

(...) If you pay attention, most offenders are sick people, because at some point in their life they were also victims. That does not justify the violence that they reproduce, but it is important to take this into consideration $\left(\mathrm{P}_{\text {health } 6}\right)$.

From the perspective of a professional connected to social assistance, the necessity for treating the aggressor is justified, given that in most situations of interfamily violence that go to trial, the offender remains in contact with the victim and the family. Thus, in the absence of a provision for treatment that allows them to see new perspectives of life and ways of establishing their family relationships, aggressors will continue to perpetrate neglectful, abusive and violent acts within their family environment.

(...) In my opinion, the aggressor is a person who needs help, who needs to see a different perspective of life $\left(\mathrm{P}_{\text {social 11 }}\right)$.

\section{DISCUSSION}

National and international studies have pointed out weaknesses in the system of protection for children and adolescents. In countries like Germany and Pakistan, the professionals do not have the obligation to notify suspected or confirmed cases of violence against children and adolescents to competent bodies; in Saudi Arabia, the notification has only become required from education and health professionals since $2009^{(10,15-16)}$.

In Brazil, the protection of children and adolescent victims of interfamily violence is ensured by the Federal Constitution of 1988 and the Statute of the Children and Adolescents (ECA) which was established in 1990, and puts the country in a prominent position for being considered as having one of the most advanced laws in the defense of child and adolescent rights. If on one hand there is the legal duty on the part of professionals to protect children and adolescents, as provided in these documents, on the other, the results of this study point out some concepts that guide their practices and determine how they relate to victims and families.

In this study specifically, professionals have neglected certain legal aspects involved in the care of children and adolescents because they consider that reporting or notifying them may, in certain situations, contribute to destroying the family. Although these professionals have considerable experience in protection services for victims, some have argued that the problems faced in the family environment/ household should be resolved privately by its members, thus preserving the autonomy of the family. These results are similar to a study carried out with 41 health professionals who report that intervening in the way parents raise and educate their children may be considered an intrusive action to parental authority. Thus, professionals are concerned not to invade into the private space of families ${ }^{(17)}$.

We also emphasize the very positive conception of professionals regarding the family and their social role, even though some studies have shown that many situations of violence, abuse and neglect against children and adolescents are experienced in the family environment/household, and parents or people with intimate relationships to the family are the main perpetrators ${ }^{(17-18)}$. Often violent or negligent acts go unnoticed by professionals who end up allowing that the violence continues to be perpetrated in the family environment, as shown in a study carried out with American doctors who consider physical punishment acceptable under certain circumstances ${ }^{(11)}$. Although violence against children and adolescents is a very common problem in many families, it is not yet viewed with the proper seriousness and priority by professionals ${ }^{(19)}$.

The conception relating to the maternal figure deserves emphasis in this study, given that for the professionals interviewed the mother is primarily responsible for caring and raising the children. When they "fail" in this process, the professionals of this study eventually consider them as complicit in situations of violence instituted in the family context. These results are similar to those obtained in a study conducted in England that found that the expectations regarding the mother figure go beyond caring for children; that is, they also become responsible for managing the father's and other family members' behavior ${ }^{(20)}$. For some authors, such attitudes may be guided by the social construction of gender, where men are connected to the sphere of economic and political life, while women take responsibility for the private sphere of the home, and so the caring for children shall be entirely their responsibility ${ }^{(18,21)}$.

As a consequence, professional practices facing situations of interfamily violence tend to not include mothers and fathers in the intervention process, thus only being responsible for the immediate care of the victims. For example, this disregards the fact that after returning to their homes, many children and adolescents remain the target of assaults, abuse and negligent acts. In the international scenario, studies indicate that the lack of intervention with other family members, including the aggressor, constitutes one of the main inadequacies in the protection network for children and adolescents. The main reason for the noninclusion of the perpetrator in these cases is due to the fact that, culturally, society and professionals tend to underestimate the willingness and the ability of these (aggressors) to change their behavior ${ }^{(22)}$.

Given these conceptions, the professionals of this study can produce practices that are non-compliant with the Statute of Children and Adolescents (ECA), which states that the rights of children and adolescents are provided with absolute priority, and the fulfillment of such rights is the responsibility of the family, society and the state. It should be emphasized that when such rights are violated, especially with regard to violence and neglect, the family should be a focus for State interventions through services 
that integrate the Unified Health System (SUS), whether specialized or not.

In addition, professionals engaged in this context have some responsibilities; among them is the obligation to notify the Child Protection Agency of suspected or confirmed cases of violence, including situations of neglect ${ }^{(4)}$.

Even with the result of these legal provisions in relation to the intervention process with victims of interfamily violence and their families, professionals of this study organize their practices based on the way they conceive this phenomenon, developing actions that do not always constitute as protective. For some authors, it is essential that professionals overcome some ideals for them to view and act on the real aspects that can endanger the development of countless children and adolescents ${ }^{(13)}$.

\section{CONCLUSION}

Based on the professional discourse, it was possible to identify the conceptions of the professionals on interfamily violence against children and adolescents, which reflected into actions which are not always protective for the victims. It is true that interfamily violence constitutes a difficult problem for intervention, as it emerges from a complex combination of social, cultural and economic factors which arouse different conceptions in the professionals regarding the same phenomenon.
In this study, violence constitutes a problem recognized by professionals engaged in protection services, however, intervening/acting on it sometimes becomes the family's own responsibility. This attitude appears to be guided by the idea that the family has the autonomy to solve their own problems. In addition, it is observed that many professionals feel shocked by certain situations, distancing themselves from victims and families. In general, the results have allowed us to highlight the positive perception of professionals regarding the family unit, where mothers and fathers are expected to be are able to play their social role in raising children.

We highlight the attitude adopted by the professionals, especially in relation to the aggressor. While some professionals judge them and condemn them, others consider the need to treat them in order to stop the cycle of violence that takes place within the family.

Although this study has some important limitations, both for the qualitative nature as well as the sample size, the results can support a reflection on the gap between the legal aspects relating to interfamily violence and actual professional practice. By understanding that interfamily violence constitutes a serious problem that affects the lives and development of many children and adolescents, it is necessary that professionals reflect on their conceptions about the phenomenon in order to prioritize the needs of victims and families.

\section{RESUMO}

Objetivo: Identificar, com base no discurso dos profissionais, suas concepções a respeito da violência intrafamiliar contra crianças e adolescentes. Método: Estudo qualitativo, realizado com 15 profissionais, que tiveram sob seus cuidados crianças e adolescentes atendidas em decorrência da violência intrafamiliar. Os dados foram coletados entre novembro de 2013 e março de 2015 , por meio de entrevistas semiestruturadas. Os dados foram organizados e analisados utilizando a técnica de Análise Textual Discursiva. Resultados: O discurso dos profissionais colocou em evidência que alguns aspectos legais em relação ao manejo da violência intrafamiliar contra crianças e adolescentes são negligenciados, omissão respaldada pela justificativa dos profissionais de preservar a família. Destaca-se o confronto entre a concepção de família como cuidadora e a família que violenta os filhos, além do posicionamento dos profissionais, os quais não incluem a família e o agressor nos processos de intervenção frente às situações de violência intrafamiliar atendidas nos serviços. Conclusão: Atuar frente à violência intrafamiliar requer do profissional romper com algumas concepções preestabelecidas para colocar em evidência as reais necessidades de vítimas e famílias.

\section{DESCRITORES \\ Criança; Adolescente; Família; Violência Doméstica; Prática Profissional.}

\section{RESUMEN}

Objetivo: Identificar, con base en el discurso de los profesionales, sus concepciones con respecto a la violencia intrafamiliar contra niños y adolescentes. Método: Estudio cualitativo, realizado con 15 profesionales que tuvieron bajo sus cuidados a niños y adolescentes atendidos en consecuencia de la violencia intrafamiliar. Se recogieron los datos entre noviembre de 2013 y marzo de 2015 , mediante entrevistas semiestructuradas. Los datos fueron organizados y analizados empleando la técnica de Análisis Textual Discursivo. Resultados: El discurso de los profesionales puso en evidencia que se descuidan algunos aspectos legales con respecto al manejo de la violencia intrafamiliar contra niños y adolescentes, omisión esa respaldada por la justificación de los profesionales de preservar a la familia. Se destaca el confronto entre la concepción de familia como cuidadora y la familia que violenta a los hijos, además de la postura de los profesionales, quienes no incluyen a la familia y al agresor en los procesos de intervención frente a las situaciones de violencia intrafamiliar atendidas en los servicios. Conclusión: Actuar ante la violencia intrafamiliar requiere que el profesional rompa algunas concepciones prestablecidas para poner en evidencia las reales necesidades de víctimas y familias.

\section{DESCRIPTORES}

Niño; Adolescente; Familia; Violencia Doméstica; Práctica Profesional. 


\section{REFERENCES}

1. World Health Organization (WHO). Word report on violence and health [Internet] Geneva; 2002 [cited 2016 Aug 05]. Available from: http://apps.who.int/iris/bitstream/10665/42495/1/9241545615_eng.pdf

2. Kalmakis KA. Adverse childhood experiences: towards a clear conceptual meaning. J Adv Nurs. 2014;70(7):1489-501.

3. Deater-Deckard K, Bornstein MH, Putnick DL, Bradley RH. Attitudes justifying domestic violence predict endorsement of corporal punishment and physical and psychological aggression towards children: a study in 25 low- and middle-income countries. J Pediatr. 2014;164(5):1208-13.

4. Brasil. Senado Federal; Secretaria Especial de Editoração e Publicações, Subsecretaria de Edições Técnicas. Estatuto da Criança e do Adolescente [Internet]. Brasília; 2005 [citado 2016 abr. 21]. Disponível em: https://www2.senado.leg.br/bdsf/bitstream/handle/id/70318/64. pdf?sequence $=3$

5. Moorea SE, Scottb JG, Ferrari AJ, Mills R, Dunne MP, Erskine HE, et al. Burden attributable to child maltreatment in Australia. Child Abuse Negl. 2015;48:208-20.

6. United Nations Children's Fund (UNICEF). Hidden in Plain Sight: a statistical analysis of violence against children [Internet]. New York: UNICEF; 2014 [cited 2016 Aug 02]. Available from: http://files.unicef.org/publications/files/Hidden_in_plain_sight_statistical_analysis_ EN_3_Sept_2014.pdf

7. Fundo das Nações Unidas para a Infância. Infância e adolescência no Brasil [Internet]. Brasília: UNICEF Brasil; 2014 [citado 2016 ago. 02]. Disponível em: http://www.unicef.org/brazil/pt/activities.html

8. Brasil. Constituição, 1988. Constituição da República Federativa do Brasil. Brasília: Senado Federal; 1988.

9. Rolim ACA, Moreira GAR, Correia CBS, Vieira LJES. A subnotificação de maus-tratos contra crianças e adolescentes na Atenção Básica e análise de fatores associados. Saúde Deb [Internet]. 2014 [citado 2015 nov. 10];102(33):794-805. Disponível em: http://www.scielo.br/ pdf/sdeb/v38n103/0103-1104-sdeb-38-103-0794.pdf

10. Silva P, Lunardi VL, Lunardi GL, Arejano C, et al. Violência intrafamiliar contra crianças e adolescents: análise reflexiva sobre as dificuldades e a atuação da enfermagem. Rev Enferm UFPE On Line [Internet]. 2014 [citado 2016 abr. 22];8 Supl.1:2498-506. Disponível em: http:// www.revista.ufpe.br/revistaenfermagem/index.php/revista/article/view/6323/pdf_5749

11. MacKenzie MJ, Nicklas E, Waldfogel J, Brooks-Gunn J. Corporal punishment and child behavioral and cognitive outcomes through 5 years-of-age: Evidence from a contemporary urban birth cohort study. Infant Child Dev. 2012;21(1):3-33.

12. Al-Dabaan R, Newton J T, Asimakopoulou K. Knowledge, attitudes, and experience of dentists living in Saudi Arabia toward child abuse and neglect. Saudi Dental J [Internet]. 2014 [cited 2016 Aug 02];26(3):79-87. Available from: http://www.ncbi.nlm.nih.gov/pmc/articles/ PMC4095046/

13. Cocco M, Silva EB, Jahn AC. Abordagem dos profissionais de saúde em instituições hospitalares a crianças e adolescentes vítimas de violência. Rev Eletr Enf [Internet]. 2010 [citado 2015 nov. 30];12(3):491-7. Disponível em: https://www.fen.ufg.br/fen_revista/v12/n3/ v12n3a11.htm

14. Moraes R, Galiazzi MC. Análise textual discursiva. 2ª ed. Ijuí: Ed. Unijuí; 2011.

15. Mogaddam M, Kamal I, Merdad L, Alamoudi N. Knowledge, attitudes, and behaviors of dentists regarding child physical abuse in Jeddah, Saudi Arabia. Child Abuse Negl. 2016;54:43-56.

16. Wekerle C. Resilience in the context of child maltreatment: Connections to the practice of mandatory reporting. Child Abuse Negl. 2013;27(2-3):93-101.

17. Carlos DM, Ferriane MGC. Family violence against children and adolescents in contexto: how the territories of care are imbricated in the picture. Rev Latino Am Enfermagem [Internet]. 2016 [cited 2016 Sep 01]:24:e2735. Available from: http://www.scielo.br/pdf/rlae/ v24/0104-1169-rlae-24-02735.pdf

18. Egry EY, Apostólico MR, Albuquerque LM, Gesnner R, Fonseca RMGS. Understanding child neglect in a gender context: a study performed in a Brazilian city. Rev Esc Enferm USP [Internet]. 2015 [cited 2016 Aug 31];49(4):555-62 Available from: http://www.scielo.br/pdf/reeusp/ v49n4/0080-6234-reeusp-49-04-0556.pdf

19. Apostólico MR, Hino P, Egry EY. Possibilities for addressing child abuse in systematized nursing consultations. Rev Esc Enferm USP [Internet]. 2013 [cited 2015 Sep 06];47(2):318-24. Available from: http://www.scielo.br/pdf/reeusp/v47n2/en_07.pdf

20. Byrne S, Rodrigo MJ, Máiquez ML. Patterns of individual change in a parenting program for child maltreatment and their relation to family and professional environments. Child Abuse Negl. 2014;38(3):457-67.

21. Okin SM. Gênero, o público e o privado. Rev Estudos Fem [Internet]. 2008 [citado 2016 ago. 04];16(2):305-32. Disponível em: http:// www.scielo.br/pdf/ref/v16n2/02.pdf

22. Ungar M, Liebenberg L, Dudding P, Armstrong M, Van De Vijverd FJR. Patterns of service use, individual and contextual risk factors, and resilience among adolescents using multiple psychosocial services. Child Abuse Negl. 2013;37(2-3):150-9. 